\title{
Animal meat products, processing and the consumer
}

By R. L. Joseph and T. W. GRIfFiths, Meat Research Department, An Foras Talúntais, Dunsinea Research Centre, Castleknock, Dublin I5, Irish Republic

Changes in consumer demand for meat are part of changing life-styles caused by technical and economic developments. The increasing application of technology to procurement, manufacture and distribution has provided a range of meat products of unprecedented variety and quality. The species acceptable as meat are limited by tradition, but they are becoming increasingly interchanged as sources of raw material. The meat-processing industry, in response to consumer demand, uses many techniques, both old and new, to make a range of products which is continually changing.

There are indications that limits to meat consumption are being reached. In addition, consumers are becoming increasingly health conscious and, although appreciative of the convenience and attractiveness of many meat products, are suspicious about fat, salt, residues and additives which may be concealed in products. Poultry meat appears to be less susceptible to this reaction and is expected to surpass beef as the principal meat of the USA by the turn of the century. In Europe the Commission of the European Communities (CEC) expects pig meat to hold first place.

\section{Meat products}

The major meat species are ruminants, cattle and sheep with their non-ruminant young, and the simple-stomached pigs and poultry. A group of increasing interest is 'game', venison, hares and wild birds. Goat meat is important in southern Europe and so is rabbit in Britain and Ireland. Carcass composition is very variable within species. Representative comparison between species is therefore misleading.

Our ancient choice of species to eat was intimately associated with folklore, religion and with the people's view of themselves. These preoccupations are still alive and flourishing even in the wealthiest of modern societies.

The range of meat products is enormous. The Organisation for Economic Cooperation and Development (OECD) lists, for the UK, eleven main categories of product for beef alone. Two major groups, canned meat (not corned) and frozen convenience meats, contained twelve subgroups each. Each group included a range of products from different companies (OECD, r984). Table I forecasts UK beef product consumption from 1979 to 1990 (OECD, 1984). The total increase is only I $5 \%$ over this period. Within this total, different groups move differently, e.g. 'old-fashioned' products like corned beef and canned meats, all subgroups, show a steady drift downwards. Frozen-meat products and ready-made meals both show 
Table I. Consumption of beef products in the UK, 1979-1990 (thousand tonnes/year) (Organisation for Economic Cooperation and Development, 1984)

$\begin{array}{lccr} & 1979 & 1985 & 1990 \\ \text { Corned beef } & 56 & 49 & 42 \\ \text { Sausages } & 170 & 172 \cdot 5 & 174 \cdot 9 \\ \text { Canned meats } & 98 \cdot 3 & 94 \cdot 6 & 91 \cdot 3 \\ \text { Cooked meat } & 9 & 8 \cdot 7 & 8 \cdot 4 \\ \text { Frozen meats (including burgers) } & 120 \cdot 6 & 129 \cdot 6 & 140 \cdot 3 \\ \text { Meat pies and sausage rolls } & & & \\ \quad \text { ready to eat } & 20 & 23 & 25 \\ \text { Meat pies for hot serving } & 115 \cdot 1 & 107 \cdot 5 & 101 \cdot 1 \\ \text { Pastes } & 4 \cdot 5 & 5 \cdot 0 & 5 \cdot 5 \\ \text { Meat-based ready meats } & 8 \cdot 0 & 11 \cdot 5 & 15 \cdot 0 \\ \text { Other } & 31 \cdot 0 & 32 \cdot 9 & 34 \cdot 8 \\ \text { Total } & 640 \cdot 4 & 644 \cdot 5 & 651 \cdot 3\end{array}$

an increase; the latter will nearly double over the decade. Sales of frozen burgers increase by $33 \%$. The sausage group are just increasing although 'beef' fall by $7 \%$, and 'flavoured' increase by $25 \%$. These products will all be made from about 250000 tonnes of carcass beef but will yield around 640000 tonnes of final product.

\section{Consumption of meat products}

Total animal meat consumption in the European Economic Community (EEC) has risen from 70 to $8 \mathrm{I} \mathrm{kg} /$ capita over the years $1973-1984$. It is projected to rise to $87 \mathrm{~kg}$ in $199 \mathrm{I}$ (Fig. I.). Within this total the four major categories, beef and veal, pig meat, poultry, and sheep and goats have performed differently. The CEC consider that pig meat will take the major share of meat consumption in the EEC, rising from $37.8 \mathrm{~kg}$ to $4 \mathrm{I} .6 \mathrm{~kg} /$ capita per annum over $1984-199 \mathrm{I}$. Poultry meat will increase from 14.8 to $16.2 \mathrm{~kg}$ but beef and veal will rise from 24.4 to $25.5 \mathrm{~kg}$ and sheep and goat meat from 3.6 to $3.7 \mathrm{~kg}$ (CEC, 1984).

The CEC point out that in contrast with price trends for pig and poultry meat, consumer prices of beef and veal have risen by $\mathrm{I} \cdot 2 \%$ per annum in real terms since I 960; sheep meat is subject to the same market constraints as beef and veal. In Britain, beef and lamb consumption have gone down since 1980 by one-fifth, while poultry has increased by $12 \%$. The reasons given are 'price' and 'health'. It is suggested that pork and poultry are more reliable in eating quality, and offer more variety than beef and mutton. Consumers find processed meats attractive, convenient and economical as a centre of meal planning. However, there is rising concern about the effects of diet on health; consumers are worried about fat and additives or contaminants which they cannot 'see' in processed meats. In the Federal Republic of Germany, consumption of processed meats (all species) has risen recently, but at different rates in different social classes.

It is suggested that the better-off are more diet and health conscious. This trend will be accelerated by the introduction of nutritional labelling. In the USA, total 


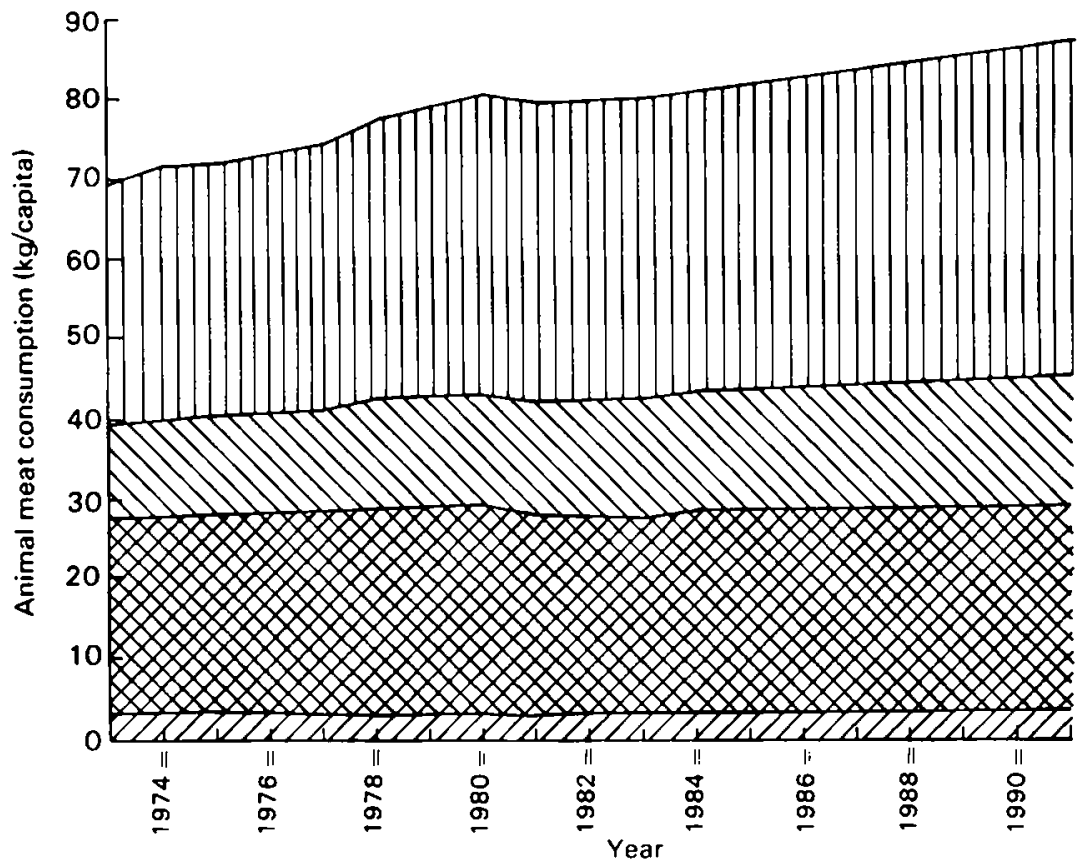

Fig. 1. Total annual meat consumption (kg/capita) in the European Economic Community,

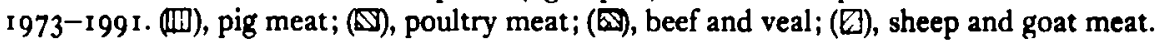

meat consumption in 1973 was $87.7 \mathrm{~kg} /$ capita, of which $66.3 \mathrm{~kg}(76 \%)$ was red meat (includes veal and pork). By 1984 the consumption of poultry had risen to $29.8 \mathrm{~kg}$ in a total of $95.4 \mathrm{~kg}$, or $31 \%$ (United States Department of Agriculture, 1984). Per capita consumption of chicken in the USA has doubled over 20 years. In the same period, beef consumption had dropped from $43 \mathrm{~kg}$ to $36 \mathrm{~kg} /$ annum. Birds of $2 \mathrm{~kg}$ slaughter weight can now be produced in 7 weeks, with a heavy, lean body and light legs. The meat is deboned and shredded and a range of chicken products can be made including frankfurters, bologna, meat loaf and hot-dogs. Machine deboning uses hitherto wasted necks and backs, and allows retail sale at half the price of pork or one-third the price of beef. But the level of total meat consumption appears to have plateaued. If an average serving is $100 \mathrm{~g}$, then USA meat consumption is enough to give 2.5 meat-based meals/d. It is unlikely to grow further. The European projection of $87 \mathrm{~kg} /$ capita per annum seems reasonable.

The partition either to fresh meat or processed meat is different between species. Customarily, pig meat is more highly processed than either chicken, or beef, veal and mutton. It has been found that turkey meat processes very well into a range of products, more usually made from pork or beef.

\section{Consumer attitudes}

Hughes (1976) has emphasized the poor state of knowledge of meat and meat products as partly responsible for low meat consumption. Many fresh products do not appear to have the right combination of 'eating quality', 'lack of waste', 
'economy' or 'usefulness'. Mince, though thought to be of poor eating quality, was scored well by his respondents as it was 'versatile' and popular with children; it was the only 'mid-week' cut eaten by a majority of the surveyed households. Prepared or processed meats were very popular and, if meat prices rise, they will be bought in preference to cheaper fresh meat cuts that require more preparation and are not likely to be so popular with the family.

In the USA, Powers et al. (1984) found that price, safety, health and nutritional value were all important to housewives. They would pay more for 'better quality' though it was not clear if this concept distinguished 'wholesomeness' from 'palatability'. The decision to purchase depended on 'rational' and 'irrational' motivation. The first comprised considerations of wholesomeness and palatability, price and nutrition and the provision of variety and balance; the second included ideas derived from personal identification with the products' meaning in a social sense. A good example of the latter is the reported preference of the German housewife for Irish meat and meat products as they are thought to come from a clean, traditional and gentle, non-industrial environment and are therefore 'better' for her family. Such associations determine the demand and the price. Further, horse meat is not eaten in the UK as it is simply not seen as a suitable item of the diet, although it is popular in France and Belgium.

Wholesomeness is a matter of health and safety. The housewife knows enough to worry about residues and additives which might affect her family's health over a period of time, and about microbes which might make them immediately sick. Consequently, since she cannot judge these matters objectively, appearance at the point of sale is very important. Hood \& Riordan (1973) showed that as meat which was displayed in a supermarket darkened, the sales declined linearly; the bright cherry-red colour was indicative of freshness, or wholesomeness. The role of safety and nutrition in consumers' attitudes to food has recently been investigated by Schutz \& Judge ( 1984 ). The increased appeal of 'natural' products is apparently a response to increasing notice being taken of possible dietary involvement in cancers, diabetes and heart disease. Low-salt or no-added-salt products are a response to concern about hypertension. The meat processor will be strongly influenced by trends like this.

Palatability of meat or a meat product can best be judged by the consumers. Their decision on their own enjoyment is quite valid and will give a clearer view of their perceptions than imposing an externally-generated continuum of variables to mark or select. Using expert opinion to assess quality does not always predict consumer response (Schutz \& Judge, I984). There is a need to broaden consumer studies through synthesis with cultural ecology, anthropology and physiology. This will assist in the design of worthwhile products, as well as serving a very real academic interest.

Food flavours, including those of meat, have been reviewed recently (Nursten, 1984). Sixty-seven compounds have been identified in the neutral fraction of 'roast beef flavour'. The characteristic flavours of meats were thought to reside in the fatty tissue, but beef and pork fats were not strongly distinguished by gas-liquid 
chromatography; sheep meat flavours were. Certain long-chain fatty acids (18:1 and $18: 3$ ) gave the highest correlation with lamb flavour.

Texture, juiciness and flavour are the criteria under which meat and meat products are usually evaluated by consumers. However, it has been recognized for a long time that texture, more specifically the tough-tender rating (for which no single term is used), is the most important factor in fresh meat. When fresh meat is tough, texture has been shown to dominate the overall judgement; when tender, then flavour is relatively more important (Dransfield et al. 1984).

Texture research has had most impact on fresh-meat production. Meat products are almost always comminuted, and the texture is controllable to a degree not possible in fresh meat. The UK demand for sausage is attributable to its combination of palatability, utility and good food value. The texture of the sausage in its multitudinous forms in Germany is critical to its acceptance. The flavour of a frankfurter might vary slightly but if the texture were to depart from the characteristic set-meat emulsion, it would not be acceptable.

Macromolecules determine the texture of most foods (Holmes, 1985). Now that the three-dimensional structure of proteins is accessible, it should be possible to make better food. Knowledge of other macromolecules, such as some polysaccharides and gums, is not so advanced.

\section{Processing}

Food processing has been reviewed recently by Mauron (1984). It is possible to define meat processing as any operation which results in goods for sale that cannot be described as 'fresh meat'. Most processes have the common objective that they will yield a food which is attractive, of a known and acceptable texture and taste, and will be safe.

Mincing and recombining to yield products as varied as the reformed steak, the hamburger or the frankfurter in order of decreasing particle size, can be done with any muscle and much non-muscle tissue. Safety is provided by cooking which destroys parasites and pathogens and their toxins. Irradiation is once more emerging as a low-cost, highly-efficient, energy-saving alternative (Dempster, 1985).

The success of products, provided they are acceptable, is determined by the merchandizing and promotion that supports them. It is estimated that each year 2000 products, not all meat, arrive on supermarket shelves in the USA, and 2000 disappear!

\section{Consumer surveys}

Studies in Britain and Northern Ireland have shown that consumers find Wiltshire-cured boar bacon as acceptable as that from gilts and castrates; it may be preferred for its leanness. Studies in Dublin on families of office and factory workers, showed that the consumers were unable to detect 'boar taint', the aroma attributed to the steroid 5- $\alpha$-androst-16-ene-3-one, and actually preferred the boar bacon for its leanness and better general appearance (Cowan \& Joseph, I98I). 
There seemed to be no case for penalizing the production and sale of bacon from boars of the type used. It was concluded that most boar meat would be accepted by consumers, although a reliable screening test for 'boar taint' in carcasses was still required.

A further study arose from complaints about salty bacon, particularly from Dublin consumers (Cowan, 1984). Back rashers of salt contents of 2.5-3.5, $4.0-5.0$ and $5.5-6.5 \%$ were prepared. The lowest level was known to be detectable by some consumers, the highest was at a level unacceptable to many. $\mathrm{A}$ total of 288 households with two adults in each were used, and they received samples of all three bacon types. Consumers were asked for their views on bacon normally bought: $57 \%$ were satisfied, in $\%$ were not, the balance had mixed opinions. One respondent in four gave 'variable salt' or 'too salty' as the main reason for dissatisfaction. The proportion of consumers preferring high-salt bacon to either medium- or low-salt bacon was $31 \% ; 53 \%$ preferred low-salt bacon, the remainder were indifferent.

\section{Conclusions}

The relations between the meat product and the consumer who will buy, eat and hopefully enjoy it are complex. The processes used will be very varied according to what is required. The consumer is also concerned about price, health, nutrition, variety and satisfying some inner cultural drives. Meat is perhaps most important because of its long association with the hunt. A product can be made from any acceptable meat animal and meat tissue can be processed into many different comminuted products. However, the success of the product will ultimately depend on its degree of acceptance by the consumers.

We are quite near the vision of H.G. Wells (1927), set by him centuries hence. It is a measure of the pace of change that his prophecy may be fulfilled in our lifetimes: '. . . The still recognizable fragments of recently killed animals, hideously charred and hacked, ... . awakened only horror and disgust. Instead were pastes and cakes of agreeable and variegated design, without any suggestion in colour or form of the unfortunate animals from which their substance and juices were derived.'

\section{REFERENCES}

Commission of the European Communities (1984). Agricultural Information Service. Brussels: CEC.

Cowan, C. A. (1984). Bacon and the Consumer. Proceedings of IIth Annual Conference: Food Marketing Issues, pp. 29-65. Dublin: An Foras Talúntais.

Cowan, C. A. \& Joseph R. L. (I98I). Irish fournal of Food Science and Technology 5, 105-1 15.

Dempster, J. F. (1985). Meat Science 12, 61-89.

Dransfield, E., Nute, G. R. \& Roberts T. A. (1984). Meat Science ro, i-20.

Holmes, A. (1985). Food Manufacture 60, 44-47.

Hood, D. E. \& Riordan, E. B. (1973). Fournal of Food Technology 8, 333-343.

Hughes, D. R. (1976). Consumer Attitudes to Meat Cuts. Newcastle upon Tyne: University of Newcastle upon Tyne. 
Mauron, J. (1984). In Proceedings of 6th International Congress of Food Science and Technology, vol. 5, pp. 30I-32 I [J. V. McLoughlin and B. M. McKenna, editors]. Dublin: Boole Press.

Nursten, H. E. (1984). In Proceedings of 6th International Congress of Food Science and Technology, vol. 4, pp. 183-221 [J. V. McLoughlin and B. M. McKenna, editors]. Dublin: Boole Press.

Organisation for Economic Cooperation and Development. (1984). Meat Balance in OECD Countries, 1976-1982. Paris: OECD.

Powers, M. E., Leone, L. P. \& Sloan, A. E. (1984). In The Meat Industry in the 2Ist Century, pp. $3^{I-37}$ [R. G. Cassens, C. F. Cook and R. G. Kauffman, editors]. Madison: University of Wisconsin.

Schutz, H. G. \& Judge, D. S. (1984). In Proceedings of 6 th International Congress of Food Science and Technology, vol. 4, pp. 229-242 [J. V. McLoughlin and B. M. McKenna, editors]. Dublin: Boole Press.

United States Department of Agriculture. (1984). Economic Research Service, Livestock and Poultry Outlook and Situation Report. Washington DC: United States Department of Agriculture.

Wells, H. G. (1927). A Story of the Days to Come. London: Ernest Benn. 